\title{
EFEKTIFITAS APLIKASI WAKTU PEMBERIAN BIOURINE PLUS DAN DOSIS PUPUK UREA TERHADAP PENINGKATAN PERTUMBUHAN DAN PRODUKSI PADI (Oryza sativa L.).
}

\author{
Mariyatul Qibtiyah \\ Fakultas Pertanian Universitas Islam Darul ‘Ulum Lamongan Jawa Timur \\ Korespondensi : mariyatulqibtiyah@unisda.ac.id
}

\begin{abstract}
ABSTRAK
Penelitian bertujuan mengetahui pengaruh waktu pemberian biourine plus dan dosis pupuk urea terhadap peningkatan produksi padi. Penelitian menggunakan rancangan Split Plot Design yang diulang 3 kali. Petak utama adalah waktu pemberian biourine terdapat 2 level yaitu: pagi dan sore. Anak petak adalah dosis pupuk urea terdapat 5 level yaitu :0, 150,200, 250 dan $300 \mathrm{~kg} \mathrm{ha}^{-1}$. Hasil penelitian menunjukkan adanya interaksi yang nyata antara waktu pemberian biourine plus dan dosis pupuk urea pada berbagai parameter yang diamati dan berbagai umur. Pada parameter pertumbuhan, perlakuan waktu pemberian biourine plus pagi dan dosis pupuk urea $250 \mathrm{~kg} \mathrm{ha}^{-1}$ serta perlakuan waktu pemberian biourine plus pagi dan dosis pupuk urea $300 \mathrm{~kg}$ $h^{-1}$ dapat meningkatkan indeks luas daun, jumlah anakan per rumpun lebih baik dari pada perlakuan lainnya. Pada parameter hasil, perlakuan waktu pemberian biourine plus pagi dan dosis urea $250 \mathrm{~kg} \mathrm{ha}^{-1}$ serta perlakuan waktu pemberian biourine plus pagi dan dosis pupuk urea $300 \mathrm{~kg} \mathrm{ha}^{-1}$ dapat meningkatkan jumlah malai per rumpun dan bobot gabah kering panen lebih baik dari pada perlakuan lainnya.
\end{abstract}

Kata kunci : biourine plus, pupuk urea, padi (oryza sativa L.), waktu pemberian, dosis

\begin{abstract}
Objective of the research was to study the effect of application time of biourine plus and dosages of urea fertilizer on increasing the growth and production of rice. The research applied the Split Plot Design by 3 replications. The main plot is the application time of biourine that comprises of 2 levels: in the morning and in the afternoon. The sub plot is the dosage of urea fertilizer that comprises of 5 levels: 0, 150, 200, 250 and 300 $\mathrm{kg} \mathrm{ha}^{-1}$. Result of the research showed a significant interaction between time of application of biourine plus and dosage of urea fertilizer on diverse-observed parameters and ages. On parameter of growth, the application time in the morning and dosage of urea fertilizer $250 \mathrm{~kg} \mathrm{ha}^{-1}$ and application time in the morning by dosage of urea fertilizer $300 \mathrm{~kg} \mathrm{ha}^{-1}$ could increase plant leaf, area indexs heigth, numbers of plantlet per clump, which are better than other treatments. On parameter of yield, the application time in the morning and dosage of urea fertilizer $250 \mathrm{~kg} \mathrm{ha}^{-1}$ and application time in the morning and dosage of urea $300 \mathrm{~kg} \mathrm{ha}^{-1}$ could increase numbers of panicle per clump and weight of harvested dry spikelets per hectare, which are better than other treatments.
\end{abstract}

Keywords : biourineplus, rice (oryza sativa L.), time of application, urea fertilizer, dosage

\section{PENDAHULUAN}

Tanaman Padi ( Oryza sativa L. ) adalah jenis tanaman biji-bijian penghasil beras. Tanaman padi hampir sepanjang tahun dapat dijumpai di lahan-lahan sawah yang produktif. Penanaman padi sepanjang tahun didasari adanya kebutuhan akan pangan bagi sebagian besar penduduk Indonesia yang makanan pokoknya nasi. Kebutuhan akan beras untuk mencukupi pangan bagi hampir setengah dari jumlah penduduk di dunia semakin tahun juga semakin meningkat seiring dengan peningkatan jumlah penduduk di dunia, sehingga tanaman padi sampai saat ini masih merupakan komoditi yang strategis karena merupakan tulang punggung ketahanan pangan khususnya di Indonesia (Suardi., 2002).

Peningkatan kebutuhan beras di Indonesia harus diikuti dengan peningkatan produksi tanaman padi. Sejak revolusi hijau, pengelolaan tanaman padi dilakukan dengan penggunaan varietas unggul, pestisida anorganik, pupuk anorganik, pengolahan lahan yang maksimal yang memang menghasilkan peningkatan produksi padi sangat pesat sehingga Indonesia mencapai 
swasembada beras pada tahun 1986. Namun disisi lain, kegiatan revolusi hijau mengakibatkan penurunan kualitas lahan tanaman padi, yaitu memburuknya sifat fisik, kimia, dan biologi tanah dan lingkungan di sekitar lahan padi (Dachlan et al., 2012).

Penggunaan biourine diharapkan mampu mengganti penggunaan bahan penyubur tanaman buatan pabrik yang harganya tidak terjangkau oleh petani sehingga kebutuhan unsur hara tanaman tercukupi dan pada akhirnya dapat mengurangi penggunaan bahan kimia untuk memenuhi kebutuhan unsur hara tanaman. Biourine plus berasal dari urine sapi yang dicampur dengan kotoran padat sapi, dan bahan -bahan organik yang difermentasikan menjadi biourine yang kemudian diberikan ke tanaman sebagai bahan penyubur tanaman diharapkan mampu mengganti penggunaan bahan penyubur tanaman buatan pabrik sehingga kebutuhan unsur hara tanaman tercukupi dan pada akhirnya dapat mengurangi penggunaan bahan kimia sebagai unsur hara tanaman. Penggunaan bahan kimia yang berlebihan juga tidak ramah bagi lingkungan di sekitar lahan pertanian (Qibtiyah, 2015)

Pemupukan merupakan faktor yang harus diperhatikan. Faktor yang mempengaruhi keberhasilan pemupukan adalah konsentrasi larutan, jenis tanaman dan waktu pemberian yang harus disesuaikan dengan aturan dosis yang sudah ditetapkan (Lingga, 2011).

Kebutuhan tanaman akan unsur hara nitrogen sangat tinggi. unsur hara nitrogen sangat dibutuhkan tanaman utamanya pada fase vegetatif. Pertumbuhan tanaman akan mengalami peningkatan yang proporsional apabila unsur hara nitrogen tercukupi. Karena apabila kebutuhan nitrogen kurang pada fase pertumbuhan tanaman, maka akan terjadi pembatasan produksi dan pembentukan selsel baru yang akan menunjang pertumbuhan dan akan berdampak pada perkembangan tanaman (Rahmantika, 2009).

Pemberian dosis unsur hara yang tepat akan mampu memenuhi kebutuhan tanaman untuk pertumbuhan dan perkembangannya, sehingga diharapkan produksi tanaman akan tinggi. Apabila dosis yang diberikan kurang, maka akan menghambat pertumbuhan dan perkembangan tanaman sehingga produksi tidak dapat maksimal.

\section{METODE ILMIAH}

Pelaksanaan penelitian di Desa Tambakrejo, Kecamatan Duduksampeyan, Kabupaten Gresik,Jawa Timur yang terletak pada ketinggian $8 \mathrm{~m}$ dpl dengan jenis tanah gromosol. Penelitian dimulai pada bulan Januari sampai April 2019. Bahan yang digunakan meliputi benih padi Ciherang, urine sapi, kotoran padat sapi (feses), jerami padi, EM-4, gula, air, pupuk urea, $\mathrm{KCl}$, SP 36 . Penelitian menggunakan rancangan Split Plot Design yang diulang 3 kali. Petak utama adalah waktu pemberian biourine terdapat 2 level yaitu: pagi dan sore. Anak petak adalah dosis urea terdapat 4 level yaitu : 0, 150, 200, 250 dan $300 \mathrm{~kg} \mathrm{ha}^{-1}$. Biourine dibuat dengan cara mencampur $5 \mathrm{~kg}$ kotoran padat sapi, 1 liter urine sapi, 50 liter air, $1 \mathrm{~kg}$ sekam padi, 1 kg jerami, 1 liter Gladiator yang diberi 0.5 I gula tetes. Semua bahan dimasukkan kedalam drum dan dibiarkan selama 2 minggu dalam keadaan tertutup. Setelah 4 minggu biourine siap digunakan. Biourine yang akan diaplikasikan terlebih dahulu diencerkan dengan air. Perbandingan konsentrasi pengenceran adalah 1 : 5. Aplikasi biourine dilakukan sesuai dengan macam perlakuan dengan cara disemprotkan pada tanaman dengan dosis $1500 \mathrm{I}^{\text {ha-1}}$. Padi ditanam dengan sistem konvensional.

Pengamatan dilakukan mulai umur 30 hst dengan interval 15 hari. Pengamatan pertumbuhan meliputi: tinggi tanaman,indeks luas daun, jumlah anakan per rumpun. Pengamatan panen meliputi:. jumlah malai per rumpun, bobot gabah kering panen per hektar. Analisa kimia tanah dan biourine dilakukan sebelum pelaksanaan penelitian (sebelum tanam) pada Tabel 1. Data pengamatan yang diperoleh dianalisis dengan analisis ragam (Uji $\mathrm{F}$ ) pada taraf $5 \%$ untuk mengetahui pengaruh perlakuan. Apabila hasilnya berbeda nyata maka dilanjutkan dengan uji BNT dengan taraf nyata $5 \%$ untuk mengetahui perbedaan antar perlakuan. 
Tabel 1. Analisa Kimia Tanah Desa Tambakrejo, Kecamatan Duduk sampeyan, Gresik - Jawa Timur

\begin{tabular}{lcc}
\hline \multicolumn{1}{c}{ Parameter } & Value & Status \\
\hline $\mathrm{pH} \mathrm{H} \mathrm{H}_{2} \mathrm{O}$ & 7.88 & Tinggi \\
$\mathrm{KCl}$ & 6.93 & Tinggi sekali \\
$\mathrm{C}$-organic (\%) & 0.90 & Redah \\
$\mathrm{N}(\%)$ & 0.10 & Rendah \\
$\mathrm{Ratio} \mathrm{C/N}$ & 9.00 & Rendah \\
$\mathrm{P}_{2} \mathrm{O}_{5}$ Olsen $(\mathrm{ppm})$ & 10.80 & Rendah \\
$\mathrm{K}(\mathrm{me})$ & 0.37 & Rendah \\
\hline
\end{tabular}

\section{HASIL DAN PEMBAHASAN}

\section{Tinggi Tanaman}

Hasil analisis ragam pada pengamatan tinggi tanaman menunjukkan adanya interaksi antara perlakuan waktu pemberian biourine plus dan dosis pupuk urea pada umur 45, 60 dan 75 hst. Pada Tabel 2 menunjukkan perlakuan waktu pemberian biourine plus pagi dan dosis pupuk urea $250 \mathrm{~kg} \mathrm{ha}^{-1}$ serta perlakuan waktu pemberian biourine plus pagi dan dosis pupuk urea $300 \mathrm{~kg} \mathrm{ha}^{-1}$ dapat meningkatkan tinggi tanaman padi lebih baik dibandingkan dengan perlakuan lainnya.

Tabel 2. Rerata tinggi tanaman padi akibat pengaruh waktu pemberian biourine plus dan dosis pupuk urea pada berbagai umur pengamatan

\begin{tabular}{ccccccc}
\hline \multirow{2}{*}{$\begin{array}{c}\text { Umur } \\
\text { (hst) }\end{array}$} & $\begin{array}{c}\text { Waktu } \\
\text { pemberian } \\
\text { biourine } \\
\text { plus }\end{array}$ & 0 & 150 & 200 & 250 & 300 \\
\cline { 3 - 7 } & & \multicolumn{5}{c}{ Dosis Pupuk Urea $\left(\mathrm{kg} \mathrm{ha}^{-1}\right)$} \\
\hline 45 & Pagi & $57.27 \mathrm{a}$ & $71.20 \mathrm{~b}$ & $76.05 \mathrm{~d}$ & $79.15 \mathrm{e}$ & $79.20 \mathrm{f}$ \\
& Sore & $57.29 \mathrm{a}$ & $70.02 \mathrm{~b}$ & $73.66 \mathrm{c}$ & $76.63 \mathrm{~d}$ & $76.69 \mathrm{~d}$ \\
\hline & BNT 5 \% & \multicolumn{5}{c}{1.82} \\
\hline 60 & Pagi & $60.07 \mathrm{a}$ & $89.93 \mathrm{c}$ & $91.46 \mathrm{~d}$ & $93.75 \mathrm{e}$ & $94.13 \mathrm{e}$ \\
& Sore & $60.13 \mathrm{a}$ & $84.61 \mathrm{~b}$ & $89.83 \mathrm{c}$ & $91.86 \mathrm{~d}$ & $92.19 \mathrm{~d}$ \\
\hline & BNT 5 \% & \multicolumn{5}{c}{0.79} \\
\hline 75 & Pagi & $88.46 \mathrm{a}$ & $100.58 \mathrm{c}$ & $103.22 \mathrm{~d}$ & $107.94 \mathrm{f}$ & $108.23 \mathrm{f}$ \\
& Sore & $88.61 \mathrm{a}$ & $99.46 \mathrm{~b}$ & $100.11 \mathrm{c}$ & $105.09 \mathrm{e}$ & $105.24 \mathrm{e}$ \\
\hline & BNT 5 \% & \multicolumn{5}{c}{0.67} \\
\hline
\end{tabular}

Keterangan: Bilangan yang didampingi huruf yang sama pada masing- masing umur menunjukkan tidak berbeda nyata pada uji BNT 5\%.

\section{Jumlah anakan per rumpun}

Hasil analisis ragam pada pengamatan jumlah anakan menunjukkan adanya interaksi antara waktu pemberian biourine plus dan dosis pupuk urea pada umur 30, 45, 60 dan 75 hst. Pada tabel 3 menunjukkan perlakuan waktu pemberian biourine plus pagi dan dosis pupuk urea $250 \mathrm{~kg} \mathrm{ha}^{-1}$ serta perlakuan waktu pemberian biourine plus pagi dan dosis pupuk urea $300 \mathrm{~kg} \mathrm{ha}^{-1}$ dapat meningkatkan jumlah anakan per rumpun lebih baik dibandingkan dengan perlakuan lainnya. 
Tabel 3. Rerata jumlah anakan per rumpun tanaman padi akibat interaksi antara waktu pemberian biourine plus dan dosis pupuk urea pada berbagai umur pengamatan

\begin{tabular}{|c|c|c|c|c|c|c|}
\hline \multirow[b]{2}{*}{$\begin{array}{c}\text { Umur } \\
\text { (hst) }\end{array}$} & \multirow{2}{*}{$\begin{array}{c}\text { Waktu } \\
\text { pemberian } \\
\text { biourine } \\
\text { plus }\end{array}$} & \multicolumn{5}{|c|}{ Dosis Pupuk Urea $\left(\mathrm{kg} \mathrm{ha}^{-1}\right)$} \\
\hline & & 0 & 150 & 200 & 250 & 300 \\
\hline \multirow[t]{2}{*}{30} & Pagi & $6.56 \mathrm{a}$ & $14.89 \mathrm{c}$ & $16.33 \mathrm{~d}$ & $18.44 \mathrm{f}$ & $18.44 \mathrm{f}$ \\
\hline & Sore & $6.44 \mathrm{a}$ & $13.11 b$ & $15.00 \mathrm{c}$ & $17.33 \mathrm{e}$ & $17.44 \mathrm{e}$ \\
\hline \multicolumn{2}{|c|}{ BNT $5 \%$} & \multicolumn{5}{|c|}{0.63} \\
\hline \multirow[t]{2}{*}{45} & Pagi & $10.56 \mathrm{a}$ & $16.11 \mathrm{c}$ & $19.11 \mathrm{~d}$ & $22.67 \mathrm{f}$ & $23.00 \mathrm{f}$ \\
\hline & Sore & $10.33 a$ & $14.22 \mathrm{~b}$ & $18.33 \mathrm{~d}$ & $20.44 \mathrm{e}$ & $20.56 \mathrm{e}$ \\
\hline \multicolumn{2}{|c|}{ BNT $5 \%$} & \multicolumn{5}{|c|}{0.89} \\
\hline \multirow[t]{2}{*}{60} & Pagi & $15.89 \mathrm{a}$ & $23.11 \mathrm{c}$ & $23.89 \mathrm{c}$ & $28.22 \mathrm{e}$ & $27.67 \mathrm{e}$ \\
\hline & Sore & $15.56 \mathrm{a}$ & $20.57 b$ & $21.67 b$ & $25.67 d$ & $26.33 d$ \\
\hline \multicolumn{2}{|c|}{ BNT $5 \%$} & \multicolumn{5}{|c|}{1.11} \\
\hline \multirow[t]{2}{*}{75} & Pagi & $17.89 \mathrm{a}$ & $25.44 \mathrm{c}$ & $26.00 \mathrm{c}$ & $29.67 \mathrm{e}$ & $30.11 \mathrm{e}$ \\
\hline & Sore & $17.56 \mathrm{a}$ & $22.22 \mathrm{~b}$ & $25.11 \mathrm{c}$ & $27.78 d$ & $28.33 \mathrm{~d}$ \\
\hline \multicolumn{2}{|c|}{ BNT $5 \%$} & \multicolumn{5}{|c|}{0.62} \\
\hline
\end{tabular}

Keterangan: Bilangan yang didampingi huruf yang sama pada masing-masing umur menunjukkan tidak berbeda nyata pada uji BNT $5 \%$.

\section{Indeks Luas Daun}

Hasil analisis ragam pada pengamatan indeks luas daun menunjukkan adanya interaksi antara waktu pemberian biourine plus pagi dan dosis pupuk urea pada umur 30 , 45, 60 dan 75 hst.
Pada tabel 4 menunjukkan perlakuan waktu pemberian biourine plus pagi dan dosis pupuk urea $250 \mathrm{~kg} \mathrm{ha}^{-1}$ serta perlakuan waktu pemberian biourine plus pagi dan dosis pupuk urea $300 \mathrm{~kg}$ ha`1 dapat meningkatkan indeks luas daun lebih baik dibandingkan dengan perlakuan lainnya.

Tabel 4. Rerata Indeks luas daun tanaman padi akibat interaksi antara waktu pemberian biourine plus dan dosis pupuk urea pada berbagai umur pengamatan

\begin{tabular}{|c|c|c|c|c|c|c|}
\hline \multirow{2}{*}{$\begin{array}{l}\text { Umur } \\
\text { (hst) }\end{array}$} & \multirow{2}{*}{$\begin{array}{c}\text { Waktu } \\
\text { pemberian } \\
\text { biourine plus }\end{array}$} & \multicolumn{5}{|c|}{ Dosis pupuk urea $\left(\mathrm{kg} \mathrm{ha}^{-1}\right)$} \\
\hline & & 0 & 150 & 200 & 250 & 300 \\
\hline \multirow[t]{2}{*}{30} & Pagi & $0.61 a$ & $0.71 \mathrm{c}$ & $0.84 \mathrm{e}$ & $0.94 \mathrm{~g}$ & $0.94 \mathrm{~g}$ \\
\hline & Sore & $0.61 \mathrm{a}$ & $0.68 \mathrm{~b}$ & $0.76 \mathrm{~d}$ & $0.89 \mathrm{f}$ & $0.89 \mathrm{f}$ \\
\hline \multicolumn{2}{|r|}{ BNT $5 \%$} & \multicolumn{5}{|c|}{0.002} \\
\hline \multirow[t]{2}{*}{45} & Pagi & $0.87 \mathrm{a}$ & $1.21 \mathrm{c}$ & $1.34 \mathrm{e}$ & $1.44 \mathrm{~g}$ & $1.44 \mathrm{~g}$ \\
\hline & Sore & $0.87 a$ & $1.18 \mathrm{~b}$ & $1.26 \mathrm{~d}$ & $1.39 \mathrm{f}$ & $1.39 \mathrm{f}$ \\
\hline \multicolumn{2}{|r|}{ BNT $5 \%$} & \multicolumn{5}{|c|}{0.02} \\
\hline \multirow[t]{2}{*}{60} & Pagi & $1.63 \mathrm{a}$ & $1.96 \mathrm{~b}$ & $2.09 \mathrm{c}$ & $2.33 \mathrm{~d}$ & $2.34 \mathrm{~d}$ \\
\hline & Sore & $1.63 \mathrm{a}$ & $1.92 \mathrm{~b}$ & $1.99 \mathrm{~b}$ & $2.11 \mathrm{c}$ & $2.13 \mathrm{c}$ \\
\hline \multicolumn{2}{|r|}{ BNT $5 \%$} & \multicolumn{5}{|c|}{0.07} \\
\hline \multirow[t]{2}{*}{75} & Pagi & $1.67 \mathrm{a}$ & $1.97 \mathrm{~b}$ & $2.17 \mathrm{~d}$ & $2.41 \mathrm{e}$ & $2.42 \mathrm{e}$ \\
\hline & Sore & $1.67 \mathrm{a}$ & $1.97 \mathrm{~b}$ & $2.10 \mathrm{c}$ & $2.19 \mathrm{~d}$ & $2.21 \mathrm{~d}$ \\
\hline \multicolumn{2}{|r|}{ BNT $5 \%$} & \multicolumn{5}{|c|}{0.05} \\
\hline
\end{tabular}

Keterangan: Bilangan yang didampingi huruf yang sama pada masing-masing umur menunjukkan tidak berbeda nyata pada uji BNT 5\%. 
Pada hasil analisis ragam pengamatan panen yang terdiri dari jumlah malai per rumpun, bobot gabah kering panen, dan bobot 1000 butir gabah menunjukkan adanya interaksi antara perlakuan waktu pemberian dan dosis biourine sapi yang ditampilkan pada tabel 5 di bawah ini.

Tabel 5. Rerata Jumlah malai per rumpun, bobot gabah kering panen $\left(\mathrm{t} \mathrm{ha}{ }^{-1}\right)$ dan karena interaksi antara perlakuan waktu pemberian biourine dan dosis urea.

\begin{tabular}{cccc}
\hline $\begin{array}{c}\text { Waktu } \\
\text { pemberian }\end{array}$ & Dosis $\left(\mathrm{kg} \mathrm{ha}^{-1}\right)$ & $\begin{array}{c}\text { Jumlah malai } \\
\text { per rumpun }\end{array}$ & $\begin{array}{c}\text { Bobot gabah kering pane (t ha } \\
1 \text { ) }\end{array}$ \\
\hline pagi & 0 & $14.56 \mathrm{a}$ & $5.12 \mathrm{a}$ \\
& 150 & $22.00 \mathrm{c}$ & $6.56 \mathrm{c}$ \\
& 200 & $22.67 \mathrm{c}$ & $7.26 \mathrm{e}$ \\
& 250 & $27.22 \mathrm{e}$ & $8.48 \mathrm{~g}$ \\
sore & 300 & $28.00 \mathrm{e}$ & $8.47 \mathrm{~g}$ \\
& 0 & $15.44 \mathrm{a}$ & $5.07 \mathrm{a}$ \\
& 150 & $20.33 \mathrm{~b}$ & $6.23 \mathrm{~b}$ \\
& 200 & $22.11 \mathrm{c}$ & $6.87 \mathrm{~d}$ \\
& 250 & $24.44 \mathrm{~d}$ & $7.61 \mathrm{f}$ \\
& 300 & $25.00 \mathrm{~d}$ & $7.82 \mathrm{f}$ \\
\hline
\end{tabular}

Keterangan : Bilangan yang didampingi huruf yang sama menunjukkan tidak berbeda nyata pada uji BNT 5\%

Jumlah malai per rumpun, Bobot gabah kering panen per hektar

Pada tabel 5 menunjukkan adanya interaksi antara waktu pemberian biourine dan dosis urea pada parameter jumlah malai per rumpun, bobot gabah kering panen. Perlakuan waktu pemberian biourine pagi dan dosis urea $250 \mathrm{~kg}$ ha'1 dan perlakuan waktu pemberian biourine pagi dan dosis urea 300 kg ha`1 dapat meningkatkan jumlah malai per rumpun, bobot gabah kering panen. Kedua perlakuan tersebut merupakan perlakuan menghasilkan peningkatan produksi padi yang lebih baik dibandingkan perlakuan lainnya.

Pemberian biourine sapi dan dosis urea memberikan pengaruh pada pertumbuhan dan produksi padi. Pada semua parameter pengamatan terdapat interaksi antara waktu pemberian biourine dan dosis urea. Pada hasil analisis ragam terdapat adanya tren kenaikan hasil seiring kenaikan dosis urea yang diberikan pada tanaman. Pemberian biourine pagi dan dosis urea $250 \mathrm{~kg}$ ha 1 serta pemberian biourine pagi dan dosis urea $300 \mathrm{~kg}$ ha'1.
Pemupukan merupakan kegiatan pemeliharaan tanaman yang bertujuan untuk memperbaiki kesuburan tanah melalui penyediaan hara dalam tanah yang dibutuhkan oleh tanaman. Dalam pemupukan, hal penting yang perlu diperhatikan adalah efisiensi pemupukan. Agar pemupukan efektif dan efisien maka cara pemupukan harus disesuaikan dengan kondisi lahan, dengan teknologi spesifik lokasi, dan dapat memanfaatkan secara optimal sumber daya alam (Istiana, 2007).

Biourine mengandung unsur hara hara organik yang dibutuhkan oleh tanaman padi selain unsur hara anorganik yang diberikan. Rahmatika (2009), menjelaskan bahwa unsur hara nitrogen sangat dibutuhkan tanaman utamanya pada fase vegetatif. Pertumbuhan tanaman akan mengalami peningkatan yang proporsional apabila unsur hara nitrogen tercukupi Karena apabila kebutuhan nitrogen kurang pada fase pertumbuhan tanaman, maka akan terjadi pembatasan produksi dan pembentukan selsel baru yang akan menunjang pertumbuhan 
dan akan berdampak pada perkembangan tanaman.

Penambahan pupuk urea yang memiliki kandungan Nitrogen tinggi juga sangat penting bagi pertumbuhan tanaman padi. Kebutuhan tanaman akan unsur nitrogen sangat tinggi. Hal ini dikarenakan nitrogen merupakan unsur yang paling utama bagi pembentukan organ tanaman karena unsur nitrogen merupakan bahan penyusun pembentukan asam amino, nucleoprotein dan amida. Ketiga bahan tersebut sangat penting dalam pembelahan sel tanaman. Pertumbuhan tanaman sangat bergantung pada pembelahan sel yang berjalan dengan baik . Hal ini dikarenakan dengan pembelahan sel yang berjalan dengan baik akan berpengaruh positif terhadap pertambahan bobot, ukuran serta volume sel tanaman. Pada tanaman padi akan berpengaruh secara langsung pada tinggi tanaman, jumlah anakan, luas daun, indeks luas daun dan berat kering tanaman. Unsur Nitrogen merupakan senyawa penting yang berperan dalam pembentukan klorofil pada tanaman. Apabila jumlah unsur nitrogen tercukupi, maka klorofil yang terbentuk juga optimal untuk proses fotosintesis tanaman (Dwijoseputro, 1994).

Menurut Lingga dan Marsono (2004), pemupukan haruslah melihat takaran atau dosis yang sesuai untuk tanaman. Jlka dosis yang diberikan kurang maka akan mempoerlambat proses pertumbuhan tanaman. Namun Jika kelebihan dosis akan menjadi racun bagi tanaman. Terutama pada unsur hara Nitrogen, jika terlalu banyak diberikan dari kebutukan tanaman padi, maka hama dan penyakit akan mudah muncul dan menghambat pertumbuhan dan produksi padi.

Pada biourine plus memiliki kandungan beberapa hormon pertumbuhan. Menurut Prawoto dan Suprijadji (1992), bahwa ternak sapi yang banyak diberikan pakan berupa hijauan, maka urine yang dihasilkan banyak mengandung hormon auksin dan giberelin. Kisaran kandungan kedua hormon tersebut yaitu hormon auksin sebesar 162-783 ppm sedangkan giberelin sebesar 0-938 ppm. Hormon auksin dan giberelin sangat penting bagi pertumbuhan tanaman, khususnya pada masa vegetatif, karena kedua hormon tersebut mempengaruhi pertumbuhan baik, pada batang, akar dan daun tanaman. Hormon giberelin tidak hanya berpengaruh terhadap perpanjangan batang, namun berguna untuk seluruh bagian tanaman. Giberelin juga dapat merangsang adanya sintesis auksin yang sangat berguna untuk perkembangan akar.

Pada urine sapi yang telah terfermentasi memiliki kandungan Nitrogen, Phospor dan Kaliaum 2,7 \% ; 2,4 \% ; 3,8 \% (Martinsari et al., 2010). Pemberian biourine melalui daun bertujuan untuk menghindari kehilangan unsur hara sebelum digunakan oleh tanaman karena unsur hara yang diberikan melalui tanah akan mengalami fiksasi didalam tanah, sehingga tidak terserap lagi oleh tanaman. Hal ini disebabkan hara yang hilang atau berkurang pada saat proses fiksasi dalam tanah, seperti akibat proses leaching, denitrifikasi dan volatilisasi sehingga ketersediaan unsur hara berkurang bagi tanaman. Pemberian biourine melalui penyemprotan pada daun di waktu pagi hari sangat efektif untuk pertumbuhan tanaman karena selanjutnya akan terjadi proses fotosintesa dengan adanya sinar matahari. Sedangkan pada sore hari stomata akan mulai menutup seiring adanya penurunan temperatur dan intensitas cahaya matahari serta tidak dilanjutkan dengan fotosintesis.

Menurut Sitompul dan Guritno (1995), menyatakan bahwa cahaya matahari merupakan faktor penting bagi pertumbuhan tanaman, hal ini disebabkan matahari merupakan faktor yang paling utama pada proses fotosintesis untuk menghasilkan fotosintat yang akan dipergunakan bagi tanaman. Selain cahaya matahari, $\mathrm{CO}^{2}$ dan unsur hara yang tercukupi akan memacu proses fotosinteis.

Proses fotosintesis yang optimal akan menghasilkan fotosintat yang optimal pada tanaman padi. Faktor - faktor eksternal seperti intensitas, suhu akan mengalami perubahan harian (diurnal). Pada pagi hari stomata mulai membuka lebar dengan adanya intensitas cahaya dan suhu yang tidak terlalu tinggi dan kelembaban yang cukup, membuat 
turgor sel penjaga meningkat sehingga stomata membuka. Pada siang hari dengan tingginya intensitas cahaya, suhu dan penguapan, mengakibatkan stomata menutup, keadaan ini akan berlanjut pada sore hari. Sehingga pemberian biourine sapi lebih efektif diberikan pada pagi hari.

Waktu pemberian biourine plus pada pagi hari diduga akan cepat diabsorbsi oleh daun karena pada pagi hari stomata akan banyak terbuka. Hal ini terkait dengan indeks luas daun pada tanaman padi yang tinggi pada kedua perlakuan tersebut. Diduga dengan adanya indeks luas daun yang tinggi maka serapan cahaya matahari juga semakin tinggi sehingga proses fotosintesa yang terjadi juga semakin tinggi.

Stomata umumnya terdapat di permukaan atas dan bawah daun. Stomata pada beberapa spesies tanaman hanya terdapat pada daun bagian bawah daun atau bagian atas saja. Pada tanaman padi, stomata terdapat pada permukaan atas dan bawah daun dengan jumlah yang sama. Berdasarkan fungsinya stomata paling banyak terdapat pada bagian bawah daun, hal tersebut dikarenakan pada bagian atas daun lebih berfungsi untuk proses fotosíntesis, banyak stomata yang berfungsi sebagai tempat pertukaran gas pada tumbuhan, sedangkan sel penjaga berfungsi untuk mengatur, membuka dan menutupnya stomata.

Menurut Salisbury dan Ross (1995), bahwa stomata akan mulai membuka ketika matahari mulai terbit. Cahaya matahari minimum yang dibutuhkan oleh stomata untuk membuka yaitu pada kisaran seperseribu sampai dengan sepertiga puluh cahaya matahari penuh. Sehingga pada waktu pagi hari, banyak stomata pada daun akan membuka sehingga unsur hara yang diberikan langsung diserap dan dipergunakan untuk kebutuhan tanaman.

Ada beberapa faktor yang mempengaruhi membuka dan menutupnya stomata yaitu faktor eksternal dan internal. Faktor eksternal yaitu intensitas cahaya matahari, konsentrasi $\mathrm{CO}_{2}$ dan hormon asam absisat. Cahaya matahari merangsang sel penutup menyerap ion $\mathrm{K}+$ dan air, sehingga stomata membuka pada pagi hari. Sedangkan
$\mathrm{CO}_{2}$ yang konsentrasinya rendah di dalam daun juga akan membuat stomata membuka. Faktor internal yang mempengaruhi membukanya stomata yaitu jam biologis tanaman yang memicu serapan ion pada pagi hari sehingga stomata membuka, sedangkan malam hari tanaman akan melakukan pembebasan ion yang menyebabkan stomata akan menutup. Faktor internal tanaman tersebut, menyebabkan pemberian biourine plus pada sore hari kurang efektif diserap oleh tanaman padi.

Unsur $\mathrm{N}$ selain berfungsi untuk meningkatkan pertumbuhan pada daerah aktif pertumbuhan. Supramudho (2008) juga menyatakan tanaman yang kekurangan nitrogen akan mengalami pertumbuhan akar yang terbatas berbeda dengan tanaman yang mendapat nitrogen yang cukup akan mengalami pertumbuhan akar yang baik. Keadaan ini akan menguntungkan tanaman karena dengan semakin besarnya volume akar yang dimiliki tanaman maka jangkauan akar juga semakin luas, sehingga mengakibatkan pengambilan unsur hara dan air oleh tanaman dapat lebih banyak. Unsur hara dan air dimanfaatkan tanaman sebagai substrat fotosintesis tanaman, dan hasil fotosintesis (fotosintat) akan digunakan untuk pertumbuhan tanaman (Rizqiani, Ambarwati, (Yuwono, 2007).

Menurut Rachmiati et al. (2004), Pemberian pupuk nitrogen sangat diperlukan tanaman untuk pembentukan atau pertumbuhan bagian-bagian vegetatif tanaman seperti daun, batang dan akar. Ketersediaan nitrogen dalam tanah dipengaruhi antara lain oleh bahan organik tanah, kadar air tanah, suhu serta fiksasi nitrogen oleh bakteri tanah. Fungsi nitrogen bagi tanaman sebagai penyusun penting dari klorofil, protoplasma, protein, peningkat pertumbuhan dan perkembangan semua jaringan. $\mathrm{K}$

Tanaman padi sangat rakus terhadap unsur hara. Sehingga sangat dibutuhkan unsur hara yang mencukupi untuk keberlangsungan pertumbuhan sampai pada masa produksi tanaman padi. Sehingga dengan unsur hara yang cukup maka produksi tanaman padi akan maksimal. 


\section{KESIMPULAN}

Hasil penelitian didapatkan adanya interaksi antara perlakuan waktu pemberian biourine plus dan dosis pupuk urea pada semua parameter pengamatan, baik pertumbuhan maupun produksi tanaman. Pada perlakuan waktu pemberian biourine plus pagi dan dosis pupuk urea $250 \mathrm{~kg}$ ha`1 dan waktu pemberian biourine plus pagi dan dosis urea $300 \mathrm{~kg}$ ha`1 menghasilkan peningkatan pertumbuhan dan produksi tanaman padi lebih baik dibandingkan perlakuan lainnya.

\section{DAFTAR PUSTAKA}

Dachlan. 2012. Inokulasi Azotobacter sp. Dan Kompos Limbah Pertanian Terhadap Pertumbuhan dan Produksi Padi Sawah. Jurnal Agrivigor 2 (2) : 117128

Dwidjoseputro. 1994. Pengantar Fisiologi Tumbuhan. PT. Gramedia Pustaka Utama. Jakarta.

Fatonah, S., D. Asih, Mulyanti dan Iriani. 2013. Penentuan Waktu Pembukaan Stomata pada Gulma Melastoma malabathricum L. di Perkebunan Gambir Kampar, Riau. Jurnal Biospesies 6 (2) : 15-22.

Istiana, Heri. 2007. Cara Aplikasi Pupuk Nitrogen dan Pengaruhnya pada Tanaman Tembakau Madura. Buletin Teknik Pertanian Vol. 12 No. 2, 2007

Lingga. 2011. Petunjuk Penggunaan Pupuk. Penebar Swadaya. Jakarta.

Martinsari, T., Y. Wijayanti, dan E. Purwanti. 2010. Optimalisasi Fermentasi Urine Sapi dengan Aditif Tetes Tebu untuk Menghasilkan Pupuk Organik Cair yang Berkualitas Tinggi. Program Kreatifitas Mahasiswa. Universitas Negeri Malang.

Lingga P. dan Marsono. 2004. Petunjuk Penggunaan Pupuk. Penebar Swadaya. Jakarta.

Prawoto, A. dan G. Supriadji. 1992. Kandungan Hormon dalam Air Seni Beberapa Jenis Ternak. Jurnal Pelita Perkebunan 2 (4) : 79-84.
Qibtiyah M, Nurul Aini, Rudy Soelistiono. 2015. The Effect of Application Time and Dosage of Biourine On Growth and Production of Rice (Oryza sativa L.)

Rahmatika. 2009. Pengaruh Presentase N (Azola dan Urea) Terhadap Pertumbuhan dan Hasil Tanaman Padi (Oryza sativa L.). Tesis. Universitas Brawijaya. Malang.

Racmiati, Y., A.A. Salim dan S. Wibowo 2004. Pengaruh berbagai takaran pupuk majemuk NPK dan kompos limbah kulit kina terhadap pH, KTK, COrganik, dan pertumbuhan tanaman kina muda di inceptisol. Jurnal Penelitian Teh dan Kina. Bandung. 9 (1-2):21-27

Rizqiani, F.N., E. Ambarwati., N.W. Yuwono. 2007. Pengaruh Dosis dan Frekuensi Pemberian Pupuk Organik Cair terhadap Pertumbuhan dan Hasil Buncis (Phaseolus vulgaris L.) Dataran Rendah. Jurnal Ilmu Tanah dan Lingkungan Vol. 7 No.1, 2007: 43-53

Salisbury, F.B. dan C.W. Ross. 1995. Fisiologi Tumbuhan Jilid 1. Sel : Air, Larutan dan Permukaan. Institut Teknologi Bandung.

Sitompul, S.M. dan B. Guritno 1995. Analisis Pertumbuhan Tanaman. Gajah Mada Univ Press. Yogjakarta.

Suardi. 2002. Perakaran Padi dalam Hubungannya dengan Toleransi Tanaman Terhadap Kekeringan dan Hasil. Jurnal Litbang Pertanian 21 (3) : $100-108$

Supramudho, N.G. 2008. Efisiensi Serapan N serta Hasil Tanaman Padi (Oryza sativa L.) pada Berbagai Imbangan Pupuk Kandang Puyuh dan Pupuk Anorganik di Lahan Sawah Palur Sukoharjo. Skripsi. Fakultas Pertanian Universitas Sebelas Maret: Surakarta.

Sitompul, S.M. dan B. Guritno 1995. Analisis Pertumbuhan Tanaman. Gajah Mada Univ Press. Yogjakarta. 